\title{
Geleneksellikten İnovasyona Giden Yolda 'Çankırı', Atıştırmalık Gıda Üretimi: Yoka Çerezi
}

\author{
Didar Üçüncüoğlu ${ }^{1,2 *}$ \\ 1,2* Çankırı Karatekin Üniversitesi, Mühendislik Fakültesi, Gıda Mühendisliği Bölümü, Çankırı, Türkiye (ORCID: 0000-0002-2640-5976), \\ didaru@karatekin.edu.tr \\ ${ }^{2}$ Yoka Fonksiyonel Gıda Sanayi Ticaret LTD. ŞTİ., Çankırı, Türkiye, d.ucuncuoglu@ yoqagida.com \\ (International Conference on Design, Research and Development (RDCONF) 2021 - 15-18 December 2021)
}

(DOI: $10.31590 /$ ejosat.1039631)

ATIF/REFERENCE: Üçüncüoğlu, D., (2021). Geleneksellikten İnovasyona Giden Yolda Çankırı, Atıştırmalık Gıda Üretimi: Yoka Çerezi. Avrupa Bilim ve Teknoloji Dergisi, (32), 1181-1187.

$\ddot{O} \mathbf{z}$

Fonksiyonel gıdalar, temel beslenme öğelerini içeren, içerisinde bulunan bir bileşen nedeniyle sağlıklı olmayı teşvik eden, bazı hastalıkları önleyen bazılarının ise oluşma sıklığını azaltan gıdalar olarak tanımlanmaktadır. Günümüzde fonksiyonel nitelik kazandırılmış 'atıştırmalık' olarak tabir edilen, ambalajlı hızlı tüketim gıdalarının üretimi, tüketimi, ithalat ve ihracatı oldukça yaygınlaşmıştır. Ülkemiz, unutulmaya yüz tutmuş pek çok geleneksel ürün barındırmaktadır. Bu ürünlerin gelecek kuşaklara aktarılması, kültürümüzün korunması ve kırsal ekonomik kalkınma açısından büyük önem arz etmektedir. Bu çalışmada, zeytinyağı üretiminde yan ürün olarak ayrılan ve teknolojik olarak işlenmeden, yakacak ya da gübre olarak kullanılan ve çevre kirliliğine neden olan, besinsel lif içeriği oldukça yüksek 'pirina' işlenerek Çankırı ili geleneksel ince (yoka) ekmeği ile buluşturulmuştur. Böylece lif miktarı yönünden zenginleştirilmiş, tuz kaynaklı sodyum oranı düşük, üretiminde yağ kullanılmayan diyet nitelikli bir atıştırmalık gıda (Yoka Çerezi) üretilmiş ve kıymetli besin bileşenleri barındıran pirina ekonomiye yeniden kazandırılmışıtır. Sunulan çalışma, Çankırı Karatekin Üniversitesi Teknokentinde yürütülen bir Ar-Ge projesinin ilk işpaketi sonuçlarını içermektedir. Buna göre, geleneksel yoka üretimi, Çankırı Karatekin Üniversitesi mezunu gıda ve kimya mühendislerince yerinde öğrenilmiş, geleneksel üretim genç kuşaklara aktarılmış, geleneksel üretim koşulları optimize edilerek endüstriyel üretime dönüştürülmüş, tüketici beğenisine uygun çeşitli baharat ve taze yeşilliklerce lezzetlendirilmiş ve nihayetinde Yoka Çerezleri üretilmiştir. Yürütülen Ar-Ge faaliyetleri sonucunda bir porsiyon Yoka Çerezinin 112 kcal enerjiye sahip olduğu bulunmuştur.

Anahtar Kelimeler: Pirina, İnce ekmek, Geleneksel gıda, Fonksiyonel gıda, Atıştırmalık gıda, Diyet, Beslenme, İnovasyon, Çankırı

\section{On the way from Tradition to Innovation 'Çankırı', Snack Food Production: Yoka Crackers}

\begin{abstract}
In general, functional foods are defined with their advantages containing basic nutritional elements, promoting health, preventing some diseases, and reducing the ratio of some disorders due to a component in it. Today, the production, consumption, import and export of packaged fast food products, which are called 'snacks' with functional qualities, have become quite widespread. In this study, pomace with high nutritional fiber content, which is separated as a by-product in olive oil production and used as an organic fire source or fertilizer without any technologic process and caused environmental pollution, was reprocessed and met with Çankırı traditional phyllo (yoka) bread. Thus, a dietary snack food (Yoka Cracker) enriched in terms of fiber content, low in salt-based sodium content, and in which no oil is used, was produced. Therefore, the olive pomace, which contains valuable nutritional components, was managed to return back to the economy. The presented work includes the results of the first workpackage of our R\&D project. Accordingly, traditional yoka-bread production was learned on-site by food and chemical engineers graduated from Çankırı Karatekin University, traditional production style was transferred to younger generations, traditional production conditions and parameters were optimized and adapted into industrial production. Yoka Crackers were flavored with various spices and fresh green vegetables. As a result of the R\&D activities carried out, it was found that a portion of Yoka Cracker has $112 \mathrm{kcal}$.
\end{abstract}

Keywords: Pirina, phyllo bread, traditional foods, functional foods, healthy snacks, diet, nutrition, innovation, Çankırı 


\section{Giriș}

Çankırı, tarihten günümüze kadar birçok medeniyeti bünyesinde barındırmış olup Hititler döneminden Mustafa Kemal Atatürk'ün şapka kanunun ilanına kadar ve bunun sonrasında da birçok tarihsel olaya şahitlik etmiş bir şehirdir. İstiklal yolu bu şehirden geçmektedir. Ticari işletmelere, hastanemize ve üniversitemize adı veren Emir Karatekin, Çankırı, Kastamonu ve Sinop'un Osmanlı topraklarına katılmasında görev alan ünlü bir komutandır. Eski çağlarda bir okyanus tabanı olan şehrin, kültürel mirası yeni renove edilen Çankırı Müzesinde sergilenmektedir. Çankırı ili ve ilçeleri, dağları, yaylaları, akarsuları, ovaları ve çayları ile zengin güzelliklere sahiptir. Her ne kadar İç Anadolu Bölgesinde de yer alsa bazen karasal bazen de karadeniz iklimi özellikleri taşımakta olup bu nedenle tarımsal ürünlerinin çeşitliliği ile ön plana çıkmaktadır. Çankırı, şehirde yaşanan Ahilik ve Yaranlık kültürü sayesinde halen Anadolu-Türk gelenek ve göreneklerinin yaşandığı illerimizden biridir. Çankırı'nın turizm açısından önemi de büyüktür. Ilgaz Dağı Milli Parkı, Kayak Merkezleri, Tuz Mağarası, Kırkpınar Yaylası, Çankırı Kalesi ve Medreseleri görülmeye değer zenginliklerimizden bazılarıdır (Anonim, 2021a; Anonim, 2021b). Çankırı'da hala geleneksel olarak beslenme alışkanlıkları devam etmektedir. Buğday vb. tahıllar ve tahıl unları ile yapılan geleneksel yemekler, sacda, yağda, firında ve tandırda pişirme gibi teknikler tercih edilmektedir. Tava çöreği, iri hamur, yazma çöreği, bükme, çullama, cızlama, mantı, gözleme ve pıhtı bunların başlıcalarıdır. Yarma, toyga, tarhana, dene, tutmaç, cümcük gibi besin değeri yüksek çobalar; yaran güveci, mantı, sarmisaklı et, iri hamur, ince ekmek ve muska, bamya aşı, gömme, yumurta tatlısı, yazma çöreği, kızılcık ekşisi gibi yemek ve içeçecekleri Çankrı'yı gastronomi turiziminde de önemli bir noktaya taşımıştır (Anonim, 2021c). Konum ve coğrafi özellikler bakımından önemli bir yere sahip olan Çankırı, aynı zamanda ülkemizin ana tuz damarları üzerinde konumlanmış olup kaya tuzu ile meşhurdur. Türk Patent ve Marka Kurumu tarafından, Çankırı'nın Yoka (İnce) Ekmek Muskası (C2017/119), Sarımsaklı Et yemeği (C2017/120), Yumurta Tatlısı (C2017/121), Tutmaç Çorbası (C2020/309), Küpecik Peyniri (C2018/005), Höşmerim Tatlısı (C2020/310), Eldivan Yağlı Çöreği'ne (C2021/000148) coğrafi tescil belgesi verilmiş ve Mahreç logosu kazanmıştır (Anonim, 2021d). Ayrıca, Çankırı Baklavası, Bütün Et, Cimcik Hamuru Çorbası, Ehlibilir, Hameyli Tatlısı, Kaya Tuzu, Kesme Kadayıfi, Kıymalısı, Kızılcık Ekşisi, Pıhtı, Tutmaç Hamuru, Yazma Çöreği, İnce Ekmek için de kuruma resmi başvurular yapılmış olup sürecin tamamlanması beklenmektedir (Anonim, 2021e). Coğrafi tescilli bu geleneksel gidalar, şehrin tanınırlığında ve kırsal kalkınma ekonomisinde önemli bir yere sahiptir. Çankırı ilçelerinde yer alan Organize Sanayi Bölgelerinde faaliyet gösteren ve gösterecek firmalara, Sanayi ve Teknoloji Bakanlığımızca 6. Seviye teşvik destekleri verilmektedir (Anonim, 2021f).

Beslenme, tüm canlıların temel ihtiyaçlarından biridir. Ancak, artan gıda çeşitliliği ve gıda sektöründeki sürekli değişen bazı uygulamalar, tüketicilerin alışveriş tercihlerini günden günde etkilemektedir. Gıdalar konusunda, 'fast-food', 'organik gıda', 'genetiği değiștirilmiş gıda', 'doğal gıda', 'fonksiyonel gida', 'hileli gida', 'vegan gida', 'vejeteryan gida', 'coğrafi işaret tescilli gıda' ve 'geleneksel gıda' gibi medyatik bazı terimler zaman zaman tüketiciler için de trend olmaktadır (BechLarsen ve Scholderer, 2007; Kocatepe ve Tirıl, 2014).

Tüketici bilincinin artması ve sürekli değişim gösteren gıda ve sağlık yönetmelikleri sayesinde gıda güvenliği, güvenilirliği ve otantisitesinin (özgünlüğünün) tespiti günümüzde oldukça önemli hale gelmiştir (Artavia ve ark., 2021). 2000'li yılların başından bu yana yaşanan küresel zorluklar, iklimsel dönüşümler, tarımsal üretimde kalitenin ve verimin devamlı olarak değişmesi, yasal olmayan taklit ve tağşiş uygulamalarının artması, g1da endüstrisini ne yazıkki kaygan bir zemin haline getirmiştir (Avrupa Birliği Araştırma Raporu, 2021).

Özellikle 2002 yılında başlayan ve dünya çapında yaşanan skandallardan bazıları, yağlarda anilin kontaminasyonu, süt ürünlerinde ve bebek mamalarında melamin tespiti, inek eti yerine at ve ya domuz eti kullanımı, yumurtalarda fipronil bulaşması, hasta hayvanların kesimi ve insan tüketimine sunulması şeklindedir (Ulberth, 2020). COVID19 pandemisi sürecinde, taklit ve tağşişli gıda satışının şimdiye kadar en az üç kat arttığı bildirilmiş olup (FAO, 2021), alarm verici bu olumsuz gelişmelerden sonra gidaların üretimi ve pazarlanması alanındaki ekonomik değişimlerin incelenmesi, dünya çapında oldukça önemli bir kriz gündem maddesi olarak değerlendirilmektedir (Brooks ve ark., 2021). Tüm bunların sonucunda, unutulmaya yüz tutmuş geleneksel gıdalara güven yeniden tazelenmiş ve tüketici tercihleri geleneksel gidalara yönelmiştir. $\mathrm{Bu}$ yönelim, yerel (kırsal) ekonomiyi canlandırmakla beraber ülke ekonomisine de dolaylı olarak katkı sağlamaktadır (Altıntaş ve Gülçubuk, 2014). Geleneksel gıdaların tüketiminde tüketici davranışlarının belirlendiği bir çalışma (Duru ve Seçer, 2019), tüketicilerin \%63.50'sinin paketlenmiş ve işlenmiş geleneksel gidalar için ek bedel ödeyebileceklerini göstermiştir. Ayrıca, geleneksel gıdaların üretiminde ve pazarlanmasında, kadın girişimcilerin rolünün arttığı değerlendirilmiştir (Özdemir, 2017).

Diğer taraftan, pandemi döneminde, dünya çapında getirilen kısıtlamalar ile genel imalat ve çiftçilik faaliyetleri dışında kalan eğitimsel ve kamusal işler büyük çoğunlukta çevrimiçi olarak uzaktan yürütülmektedir. Bilgisayar başında geçilen sürenin artışı, pekçok yaş grubunda beslenme alıșkanlıklarını da değiştirmiştir. $\mathrm{Bu}$ süreçte en çok tercih edilen gıdalar, sandiviç ya da dürüm tarzı ekmek ya da lavaş arasında tüketilen ve ev ortamında hazırlanabilen gidalar, tek porsiyonluk gida katk1 maddesi içeriği yüksek ambalajlı gıdalar ile hazır atıştırmalıklar olmuştur. Atıştırmalık gıdalar genel olarak kalori değeri yüksek ancak günlük diyet için gerekli besleyici besin bileşenleri varlığ düşük olan gıdalar tanımlanmaktadır. Bu gruba, soslu ya da sossuz kuruyemişler, cipsler, kraker, bisküvi, gofretler, çerezler, çikolata kaplamalı ürünler, şekerlemeler, çiğnenebilir/emilebilir şekerli gıdalar girmektedir. Atıştırmalık pazarının ürün yelpazesi her geçen gün genişlemektedir. Günlük diyette atıştırmalık gidaların sıklıkla tercih edilmesi pek çok sağlık sorununu da beraberinde getirmektedir (Güneş, 2014; Değerli, 2019). Bu nedenle günümüzde atıştırmalık gıdalara fonksiyonel nitelik kazandırılması önemli bir ihtiyaç haline gelmiştir.

TÜBİTAK-1512 BiGG programı kapsamında desteklenerek, Çankırı ili, Çankırı Karatekin Üniversitesi Teknoparkı bünyesinde kurulan şirketimiz, yüksek lifli, düşük yağ ve sodyum içeriğine sahip, diyet nitelikli, fonksiyonel gıda üretimi alanındaki Ar-Ge faaliyetlerine odaklanmıştır. 
Sunulan bu çalışmada ise, zeytinyağı üretiminde atık olarak ayrılan besinsel lif içeriği yüksek zeytin posası (prina) ile Çankırı ili geleneksel ince (yoka) ekmeği inovatif bir yolla işlenmiş, yeni geliştirilen atıştırmalık çerez arıştırma ve geliştirme faaliyet sonuçları değerlendirilmiştir. Projenin ilk ana iş paketinde, geleneksel üretim yönteminin öğrenilmesi ve yeni kuşaklara aktarılması amacıyla yerinde üretim ve fiziki ölçümlerin yapılması yer almaktadır. Bu nedenle ilk aşamada bu verilerin yayımlanması hedeflenmiştir.

\section{Materyal ve Metot}

\subsection{Materyal}

Bu araştırmada 'Yoka Çerezi' üretiminde kullanılan ana materyaller, tam buğday unu, çekirdeksiz prina, kaya tuzu, taze baharat ve aromatik bazı bitkilerdir. Yoka Çerezi üretimi sırasında, öncelikle geleneksel yolla ince ekmek yapılmış, ardından prina ile besin değeri arttırılmış, taze baharatlar ile aroması zenginleştirilmiştir.

Kepek oranı yüksek tam buğday unu Çankırı ili yerel değirmenlerinde üretilmiştir.

İnce ekmeğin geleneksel üretimi, Çankırı'nın üç farklı ilçesinde üç farklı evde yapılmıştır. 9 farklı üretim reçetesi değerlerinin ortalaması alınarak imalathanemizde de Şekil 1'de verilen akış şemasına uygun olarak üretim yapılmıştır.

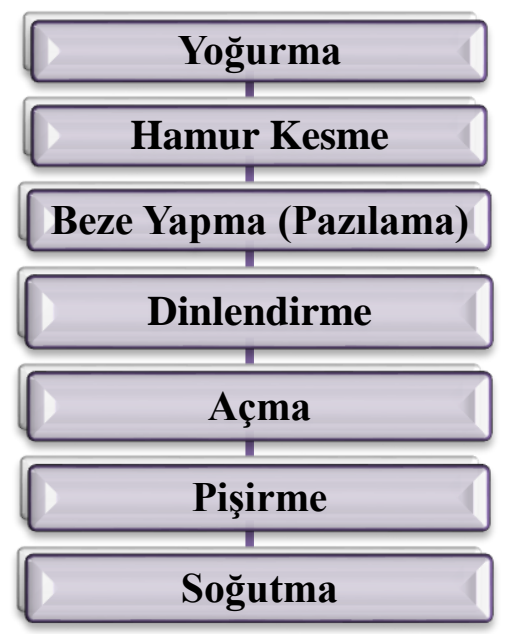

Şekil 1. Ince Ekmek Yapım Aşamaları

Şekil 1'e göre, yoğurma işlemi sırasında, $1 \mathrm{~kg}$ tam buğday ununa yaklaşı $560 \mathrm{~mL}$ su ve $0.020 \mathrm{~kg}$ tuz eklenerek 10 dakika yoğurma yapılmıştır. Yoğurulan hamur yastağaç (tahta masa) üzerine alınarak hafif unlanarak bütün şekilde elle tekrar yoğurulmuştur. Kısa süreli yoğurulan hamur, '1sra' (spatula benzeri bir mutfak aparatıdır) ile bezelere bölünmüştür. 150 gramlık bezeler yuvarlanmış, üzerleri örtülerek 10 dakika dinlendirilmiştir. Dinlendirilen pazılar, yastağaç üzerine alınarak açılmıştır. Sac üzerinde pişirilme yapılmadan önceki yufka çapı $59.5 \mathrm{~cm}$ olarak ölçülmüştür. Açılan hamurlar, pişirme sacı üzerinde 5 s kadar arkalı önlü ve uçları döndürülerek pişirilmiştir. Daha sonra pişirilen ince ekmekler, soğutma amacıyla ayrı bir yere alınmıştır. Üretime ait bazı görseller Şekil 2'de verilmiştir.
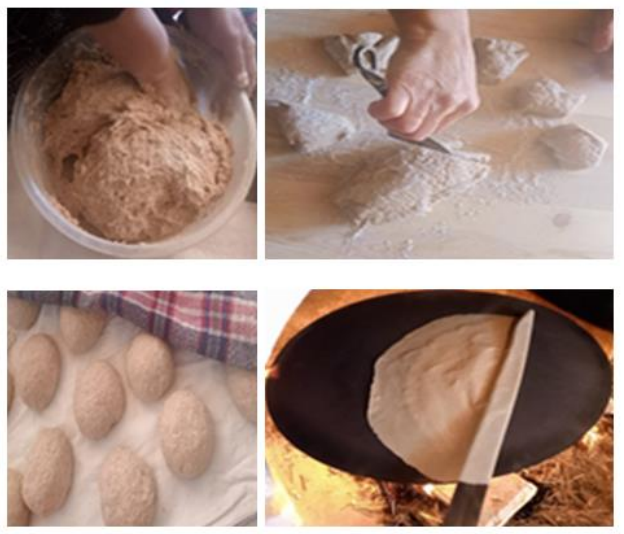

Şekil 2. Geleneksel ince ekmek yapımından bazı kareler

Yoka Çerezi imalatı sırasında kullanılan çekirdeksiz prina Semercioğlu Zeytincilik ve S.S. Edremit İskele Mahallesi Tarımsal Kalkınma Kooperatifi'ne (Edremit, Balıkesir) bağlı diğer zeytinyağı üreticilerinden temin edilmiştir. Yoka Çerezi, imalatı sırasında prinada kalan yağ dışında ekstra yă̆ kullanılmamıştır. Ayrıca, imalat sırasında tuz ve gıda katkı maddesi kullanılmamıştır. Yoka çerezi imalatı sırasında kullanılan baharatlar muhtelif marketlerden, taze yeşillikler ise yerel pazarlardan alınmıştır. Yoka Çerezi yapım aşamaları Şekil 3 'te verilmiştir.

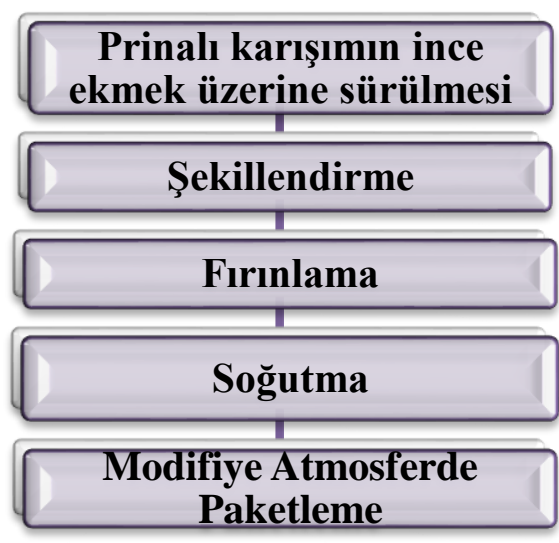

Şekil 3. Yoka Çerezi Yapım Aşaması

Atıştırmalık fonksiyonel nitelikteki Yoka Çerezi'nin üretimi Şekil 3'de verildiği üzere tam buğday unundan yapılan kepek içeriği yüksek ince ekmekleri hammadde olarak kullanımı ile başlamaktadır. Çekirdeksiz zeytin prinası çeşitli baharatlar ve taze yeşillikler ile karıştırıldıktan sonra bir miktar su ile sürülebilir kıvama getirilmiş ve ardından ince ekmeklerin üzerine sürülmüştür. Endüstriyel şekillendirme bıçakları kullanılarak üçgen, kare ya da dikdörtgen vb. şekiller verilmiştir. $180^{\circ} \mathrm{C}^{\prime}$ yi geçmeyecek sıcaklıkta tepsili konvansiyonel firında pişirme işlemi yapılmıştır.

Proje kapsamında üretilen farklı şekil ve baharat çeşnili Yoka Çerezleri, depolama süresinin uzatılması ve tazeliğini koruması için azot atmosfer varlığında paketlenmiştir. Ürün çeşitliliğini ve raf ömrü süresini arttırmak amacıyla $\mathrm{Ar}-\mathrm{Ge}$ faaliyetleri devam etmektedir. Yoka çerezi üretiminden bazı kareler Şekil 4'te gösterilmiştir. 


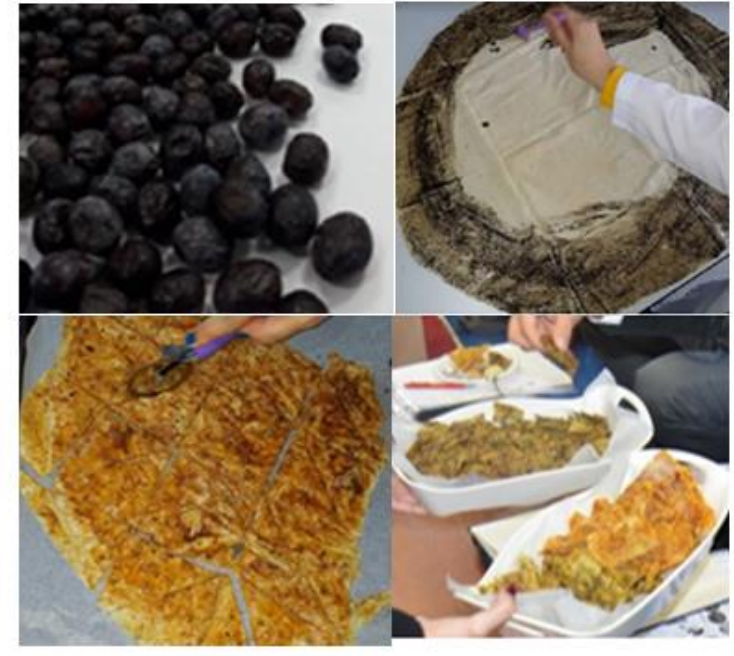

Şekil 4. Ar-Ge ölçekli Yoka Çerezi yapımından bazı kareler

\subsection{Yöntemler}

\section{Geleneksel İnce ekmek fiziki parametrelerinin belirlenmesi}

Çankırı'nın belirlenen ilçelerinde (n:3), belirlenen ayrı köylerde (n:3) olmak üzere 9 adet üretim yapılmıştır. Her üretim sırasında 20'şer ince ekmek gelişi güzel seçilerek fiziksel analizleri yapılmıştır. Fiziksel analiz olarak TS 10443 (1992) yufka standardında yer verilen parametreler ölçülmüştür. Bu parametreler, iç ve dış kalınlık, çap ve 1 adet ince ekmeğin kütlesi şeklindedir.

\section{Verim ve Maliyet Analizleri}

İnce ekmek üretiminde kullanılan hammaddeler, kullanım oranları ve bu reçete ile elde edilen ince ekmek sayısı belirlenmiştir.

İnce ekmek ve Yoka Çerezi ürünleri için maliyet analizleri ayrı ayrı yapılmıştır.

İnce ekmek yapımında tam buğday unu, su ve tuz; Yoka çerezi yapımında ise ince ekmek, prina ve baharat maliyetleri hesaba katılarak, 'hammadde maliyeti' olarak tanımlanmıştır.

Son ürün (Yoka Çerezi) maliyetinin \%30'unun hammadde maaliyeti, \%40'nın enerji, temizlik ve işgücü maaliyetleri, $\% 20$ 'sinin tanınırlık ve yayın faaliyetleri maliyetleri ve \%10'nun beklenmeyen giderlerden oluştuğu kabul edilmiştir.

\section{Besin Değerinin Belirlenmesi}

Üretimde kullanılan başlıca hammaddelerinin besin bileşenleri belirlenmiştir.

İmalatta kullanılan reçete temel alınarak Yoka Çerezinin ortalama besin değeri ve enerji miktarı belirlenmiştir.

Burada $1 \mathrm{~g}$ karbonhidratın ve proteinin $4 \mathrm{kcal}, 1 \mathrm{~g}$ yağın 9 kcal enerji verdiği kabul edilmiş̧tir (Uzun, 2008).

\section{Araştırma Sonuçları ve Tartışma}

\section{Fiziksel Analiz Bulgulart}

Geleneksel yöntemle üretilen ince ekmeklerin fiziksel özellikleri Tablo 1'de verilmiştir. Buna göre, Çankırı ilinde üretilen ince ekmeklerin dikey çapı genel ortalaması $55.5 \pm 2.8$ $\mathrm{cm}$, yatay çapı genel ortalaması $55.7 \pm 3.2 \mathrm{~cm}$, dış kalınlık genel ortalaması $0.6 \pm 0.1 \mathrm{~cm}$, iç kalınlık genel ortalaması $0.5 \pm 0.1$ ve ince ekmek kütlesi genel ortalaması $129.5 \pm 8.2 \mathrm{~g}$ olarak hesaplanmıştır. Burada, her bir ince ekmeğin yatay ve dikey çaplarının ayrı ayrı ölçülmesinin nedeni, bezelerin elle açılması, açma şeklinin kişiye değişmesi ve tam bir daire olmayışıdır. Ayrıca, oklava ile açılan yufkaların her zaman halkanın dışına doğru daha kalın olduğu bilinmektedir. Ölçüm sonuçları da bunu göstermiştir. Çalışmanının başlangıç aşaması olan köylerdeki geleneksel üretimin izlenmesi sırasında en farklı sonuçların 2 numaralı köyde olduğu gözlemlenmiştir. Pişirme sonucu elde edilen ince ekmekler bu köyde daha küçük çapta üretilmiş olup, diğer köylerden daha ağır kütlelere sahiptir (kalınlıkları aynı olmasına rağmen). $\mathrm{Bu}$ sonuç, 2 numaralı köyde kullanılan tam buğday ununun su kaldırma kuvvetinin yüksek olması ile açıklanmıştır.

\section{Verim ve Maliyet Analizleri Bulgulart}

Geleneksel üretim yaptırılan köylerde kullanılanan ortalama tam buğday unu, tuz ve su miktarları Tablo 2'de verilmiştir. Buna göre 1. köy de ortalama olarak $8 \mathrm{~kg}$ un kullanılarak 96 adet ince ekmek elde edilmiştir. 2. Köyde ise $4 \mathrm{~kg}$ un kullanılarak 40 tane, 3. Köyde ise $3 \mathrm{~kg}$ un kullanılarak 26 tane ince ekmek üretilmiştir. Çankırı ili genel ortalaması alındığında, toplam $5 \mathrm{~kg}$ tam buğday ununa $3.2 \mathrm{~kg}$ su ve $100 \mathrm{~g}$ tuz ilavesiyle 54 tane ince ekmek üretilebildiği görülmüştür. Buradan, kabaca $1 \mathrm{~kg}$ undan 10 tane ince ekmek çıkabileceği anlaşılmaktadır.

$1 \mathrm{~kg}$ tam buğday unu $\mathrm{kg}$ fiyat1 $40.00 \mathrm{TL}$ (Ilgaz atatohum tam buğday unu referans alınmıştır), $1 \mathrm{~kg}$ tuzu fiyatı $15.00 \mathrm{TL}$ (Çankırı doğal kristal kaya iyotsuz katkısız sofra tuzu referans alınmıştır) ve $1 \mathrm{~kg}$ su fiyatı $14.30 \mathrm{TL}$ (Aski ücret tablosu referans alınmıştır) olarak kabul edildiğinde, 1 tane ince ekmeğin sadece hammadde maliyetinin yaklaşı $5 \mathrm{TL}$ olduğu görülmektedir. Ev ölçeğinde ve ya fabrika ortamında üretim yapılmasına bağlı olarak 'Yöntemler' bölmündeki kabul ile ince ekmek maaliyeti 16.67 TL'yi bulabilmektedir. Bu makalenin hazırlandığı tarihte Çankırı yerel pazarında $1 \mathrm{~kg}$ ince ekmek (kalınlığına göre 5-7 tane girmektedir) 17.00 TL'ye satılmaktadır. Ancak, pazarda satılan ince ekmeklerin maaliyeti düşürmek amaciyla standart kalite buğday unundan (beyaz undan) yapıldığı unutulmamalıdır. 
European Journal of Science and Technology

Tablo 1. Ince ekmeklerin fiziksel özellikleri

\begin{tabular}{|l|c|c|c|c|l|}
\hline Lokasyon & Dikey çap, cm & Yatay çap, cm & Dış kalınlık, cm & İç kalınlık, cm & Kütle, g \\
\hline 1. İlçe & $57.4 \pm 2.97$ & $58.1 \pm 3.33$ & $0.7 \pm 0.08$ & $0.5 \pm 0.09$ & $121.6 \pm 4.43$ \\
\hline 2. İlçe & $51.5 \pm 3.12$ & $51.8 \pm 3.34$ & $0.6 \pm 0.09$ & $0.5 \pm 0.08$ & $135.3 \pm 9.33$ \\
\hline 3. İlçe & $58.2 \pm 2.19$ & $56.8 \pm 2.80$ & $0.6 \pm 0.10$ & $0.5 \pm 0.07$ & $130.1 \pm 10.96$ \\
\hline
\end{tabular}

\section{Besin Değerinin Belirlenmesi}

Buğday çeşidi ve hasat sezonuna bağlı olarak tam buğday ununun kuru madde de karbonhidrat miktarı yaklaşık \%78-82, protein miktarı \%10-14, yağ oran1 \%1-3 arasında değişmektedir. Kalan kısım karbonhidrat yapısında olmayan (sindirilemeyen) besinsel lifler, vitamin, mineral ve diğer minör bileşenlerden oluşmaktadır. Ayrıca karbonhidrat yapısında olan ve kısmen sindirilebilir besinsel lif oranı ise \%12 civarındadır (Kalkan ve Özarık, 2017).

Prina, sert çekirdekli zeytin meyvesinden presyon yöntemi ile zeytinyağı elde edildikten sonra ayrılan katı formdaki atık maddedir. Ülkemizde prina işlem teknolojisi gelişmemiş bir alan olup çoğunlukla yakacak, hayvan yemi ya da gübre olarak kullanılmaktadır. Tarım arazilerine dökülen pirina içerisinde kalan yağ, toprak yüzeyini kaplayarak, topraktaki faydalı mikroorganizmaların gelişmesini ve ağaç köklerinin hava almasını önlemekte ve bu durum verimsizleşmeye neden olmaktadır. Türkiye'de piranayı değerlendiren büyük bir sanayi kolu mevcut değildir. Özellikle Ege Bölgesi zeytin ve zeytinyağ üreticisi olup bunu değerlendirememesi nedeni ile ekonomik kayıp ve çevresel tehdit oluşturmaktadır $\mathrm{Bu}$ nedenle pirinanın kullanım yollarının araștırılması gerekmektedir. Pirina, zeytinyağının üretim yöntemine göre değişik kimyasal kompozisyonlar gösterebilmektedir. Ülkemizde zeytinyağ üretiminde yaygın olarak 2 ve 3 fazlı ekstraksiyon sistemleri kullanılmaktadır. 2 fazlı sistemde ayrılan prina 'sulu prina' şeklinde tanımlanmakta ve içinde kısmen yağ, karasu ve çekirdek barındırmaktadır. 3 fazlı sistemde ayrılan prina ise çok daha kuru olup yağ ve karasuyu eser miktarda barındırmaktadır. Bu prinada da çekirdek bulunmaktadır (Demirtepe, 2008).

Pirinanın besin bileşenlerin belirlendiği çalışmalarda yaklaşık olarak kurumadde de karbonhidrat oranın \%75-80, kül oranının $\% 5$, protein oranının en fazla $\% 10$, ham yağ oranın $\% 6$ 15 ve ham selüloz oranının $\% 50$ civarında olduğu bildirilmiştir. Pirina, polifenolik bileşikler ve tanenler yönünden de oldukça zengindir (Sansoucy, 1985; Molina-Alcaide ve Yanez-Ruiz, 2008).
Tablo 2. Ince ekmek yapımında kullanılan hammadde miktarları ( $\mathrm{kg})$

\begin{tabular}{|c|c|c|c|}
\hline Lokasyon & $\begin{array}{c}\text { Tam } \\
\text { buğday } \\
\text { unu }\end{array}$ & Tuz & Su \\
\hline 1. İlçe & 8.00 & 0.18 & 4.80 \\
\hline 2. İlçe & 4.00 & 0.05 & 2.75 \\
\hline 3. İlçe & 3.00 & 0.05 & 2.10 \\
\hline Ortalama & 5.00 & 0.1 & 3.2 \\
\hline
\end{tabular}

$\mathrm{Bu}$ projede ise çekirdeksiz kuru prina kullanımı tercih edilmiştir. Çekirdek prina üretimi genel olarak iki şekilde yapılmaktadır. Bunlardan ilki, çekirdeği alınmış zeytinden zeytinyağı üretmek vesilesiyle çekirdeksiz atık prina elde etmek, ikincisi ise çekirdekli prinadan tasarlanan bir makine aparatı yardımıyla çekirdek parçalarının ayrılmasıdır. Pirinanın çekirdeğinin uzaklaştırılması yanıcı organik madde miktarını ve ham selüloz değerini oransal olarak azaltmakta, buna paralel olarak diğer besin bileşenlerini ve çekirdek kaynaklı olmayan besinsel lif miktarını da oransal olarak arttırmaktadır.

Proje kapsamında üretilen geleneksel ince ekmekten üretilen Yoka çerezinin besin değeri tablosu ise Tablo 3'de verilmiştir. $\mathrm{Bu}$ tabloda, kullanılan tam buğday ununun kuru madde de $\% 80$ karbonhidrat, $\% 12$ protein ve $\% 2$ yağ içerdiği; pirinanın ise kurumadde de $\% 30$ karbonhidrat, $\% 7$ protein ve $\% 5$ yağ içerdiği hesaba katılarak enerji değerleri hesaplanmıştır. Bir ince ekmekten yaklaşık $120 \mathrm{~g}$ çerez üretimi yapıldığ kabulü ile $30 \mathrm{~g}$ lık bir Yoka Çerezi ambalajlı ürünün tüketilmesi halinde 112 kcal enerji sağlanacaktır. $100 \mathrm{~g}$ ürün için enerji miktarı $373 \mathrm{kcal}$ olarak hesaplanmıştır. Yoka çerezi nihai ürününde besinsel lif oranı en fazla $\% 20$ ve tuz oranı en fazla \%1 olarak bulunmuştur. Enerji değerleri hesaplanırken baharat ve taze otlar ile tuz ve besinsel lif kaynaklı değerler ihmal edilmiştir. 
Tablo 3. Yoka çerezi yaklaşık besin ve kalori değerleri

\begin{tabular}{|l|l|l|l|}
\hline Bileşenler & $\begin{array}{l}\text { Yoka Çerezi } \\
(100 \mathrm{~g} \mathrm{da})\end{array}$ & $\begin{array}{l}\text { Enerji } \\
\text { Miktarı, } \\
\text { kcal } \\
(100 \mathrm{~g} \text { da })\end{array}$ & $\begin{array}{l}\text { Enerji } \\
\text { Miktarı, } \\
\text { kcal } \\
(30 \mathrm{~g})\end{array}$ \\
\hline Karbonhidrat & 70 & 280 & 84 \\
\hline Protein & 12 & 48 & 14 \\
\hline Yağ & 5 & 45 & 14 \\
\hline
\end{tabular}

\section{Sonuç}

Dünya Gıda ve Tarım Örgütü'nün açıklamasına göre (2014), gıda tedarik zincirinde oluşan ve üretilen birçok gıdanın ve yan ürünlerinin israf edildiği raporlanmıştır. İsraf edilen bu gıdaların ve atıklarının aslında küresel boyutta yaşanılan açlığın önlenmesinde kullanılabileceği düşünülmektedir. Çevre Koruma Ajansı EPA'nın, atıkların yeniden kullanılması, geri dönüşümünün sağlanması yada bunlardan kompost elde edilmesi, kaynağında atık oluşumunun azaltılması ve ya atık oluşumunu engelleyen prosesler geliştirilmesi gibi önlem önerileri olmuştur (FAO, 2014). Bu projede, zeytincilik sektörü atıklarından, organik içeriği yüksek olduğu için çoğunlukla yakacak ve ya gübre olarak kullanılan pirina, çekirdeksiz hale getirilip kurutularak atırmalık gıda üretiminde ingredient olarak değerlendirilmiştir.

'Diyet' kelimesi ilk olarak zayıflama kavramını çağrıştırsa da kişiye özgü bir günlük beslenme programını tanımlamakta olup belli bir hastalığa karşı ya da düzensiz kilo verip almaya karşı hazırlanabilen bir beslenme programıdır. Diyet programarında, cinsiyet, yaş, kilo, boy, yağ ve kas oranı, var olan hastalıklar ile aynı zamanda günlük fiziksel aktivitelere göre alınması gereken enerji ve protein oranları dikkate alınmaktadır. Türkiye istatistik Kurumu'nun verilerine göre (2019) 15 yaş ve üstü obez bireylerin oranın 2016 yılında \%19.6 iken, bu oran 2019 yılında \%21.,1 olduğunu açıklamıştır. Aynı zamanda Cinsiyet ayrımına bakıldığında ise 2019 yılında kadınların \%24.8'inin obez olduğu ve erkeklerin ise \%17,3'ünün obez niteliğini taşıdığını açıklamıştır (Anonim, 2019a). Pandemi kısıtlamaları ve bilgisayar başında yürütülen iş tiplerinin çoğalması nedeniyle çalışanların fiziksel aktiviteleri günümüzde sınırlanmış durumdadır. Bu süreçte atıştırmalık gıda tüketimi artmıştır. Atıştırmalık gıdaların büyük çoğunluğu, besin değeri yönünden yetersiz ancak enerji miktarı yönünden oldukça yüksek kalori değerlerine sahiptir. $\mathrm{Bu}$ nedenle son dönemde yüksek kilolu ve obez insan sayısı daha da artmıştır.

Fonksiyonel gıdalar, çoğunlukla saflaştırılan bir besin komponenti ile zenginleştirilmiş, insan sağlığını belirli bir yönden destekleyen gıdalardır. Son yıllarda yapılan çalışmalar, besinsel lif oranın arttırıldığı ve sindirim sistemini hızlandıran besinler üzerinedir. Bu projede, atıştırmalık gıdalardan 'çerez' üretimine odaklanılmıştır. Çerez üretinde tam buğday unundan yapılmış geleneksel ince ekmek, besinsel lif yüksek prina ve lezzetlendirici olarak çeşitli taze baharat ve yeşillikler kullanılmıştır. Son ürün olan cips benzeri atıştırmalıkta tuz olarak kaya tuzu tercih edilmiş, hesaplanan miktar $(<\% 1)$ sadece ince ekmek hamuruna katılmıştır. Çerez baharat sosunda tuz kullanılmamıştır. $\mathrm{Bu}$ nedenle, fazla kullanımı halinde, başta damar sertliği, hipertansiyon ve felce neden olan tuz kaynaklı sodyum içeriği oldukça düşüktür. Çerez üretiminin hiçbir aşamasında ekstra yağ kullanılmamıştır. Son üründe tespit edilen yağ, sadece prina ve tam buğday unu kaynaklıdır. Böylelikle son ürünün kalori değeri oldukça düşük olup diyet nitelik taşımaktadır. Ayrıca Yoka Çerezi üretimi sırasında hiçbir gıda katkı maddesi kullanılmamıştır. Taze ve hijyenik ortamda üretilen ürünün raf ömrü depolama sıcaklığına bağlı olmakla birlikte 2-3 ay arasında değişmektedir. Yoka Çerezi atıştırmalık gıdasının en önemli özelliği ise besinsel lif yönünden zenginleştirilmiş olması ve bu nedenle kazandığı fonksiyonel niteliktir.

Çankırı, tarımsal yapısı, hayvansal kaynakları, sanayisi, maden varlıkları ve var olan potansiyeli ile gelişme gösteren bir şehir olup sanayileşme faaliyetleri çeşitli teşvik uygulamaları ile hız kazanmıştır. Ankara ve İstanbul'a yakın konumda yer alan 6. bölge desteklerinin sağlandığı OSB'lere ev sahipliği yapmaktadır. Şabanözü OSB (Organize Sanayi Bölgesi), Korgun OSB, Yakınkent OSB ve Çerkeş OSB ile yaklaşık 50 firma ve 6000 çalışanı ile çeşitli sektörlerde üretim yapılmaktadır Çankırı'nın birden fazla OSB ye sahip olması çarpık sanayileşmeyi engellemesine, çevre sorunlarının önüne geçmesine ve mevcut olan kaynakları rasyonel olarak kullanmasına fayda sağlamıştır. Bu proje ile şehir kırsal kalkınmasına ve yerel ekonomiye ivme kazandırmak, geleneksel kültürümüzün en önemli bileşenlerinden olan geleneksel mutfağımızı koruyarak mühendislik teknikleri ile inovatif özellikli sağlıklı bir atıştırmalık üretmek hedeflenmiştir. Hedefe uygun olarak atılan adımlar ile geleneksel ince ekmek yapımı, 'yerinde' öğrenilmiş; genç kuşak gıda mühendislerine aktarılmış; bu genç ellerde geleneksel üretim verilerine uygun, fabrikasyon üretim koşulları belirlenmiş; günümüzün en çok tüketilen atıştırmalık gıdalarından biri olan cipse dönüştürmüş ve bu cipsin diyet ve fonksiyonel nitelik kazanması sağlanmıştır.

\section{Teșekkür}

Bu proje, TÜBITTAK TEYDEB 1512 - Teknogirişim Sermayesi Desteği Programı (BIGG) kapsamında desteklenmektedir (2021-2022).

2210410 nolu projenin ismi 'Fonksiyonel Atıştırmalık: Yoka Çerezi' olup, Şirket yönetimi ve çalışanları olarak TÜBITAK'a finansal destekleri için teşekkür ederiz. 


\section{Kaynakça}

Altuntaş, A., Gülçubuk, B. (2014). Yerel Kalkınmada Yaygınlaşan Bir Araç Olarak Geleneksel Gıdalar ve Geleneksel Gıda Mevzuatının Yaygınlaştırılabilirliği, Journal of Agricultural Faculty of Gaziosmanpaşa University, http://ziraatdergi.gop.edu.tr/Makaleler/2031600564_7381.pdf Erişim Tarihi: Kasım 2021.

Anonim, (1992). Türk Standartları Enstitüsü, TS 10443. https://kib.org.tr/files/downloads/sirkuler/2017259ek1.pdf Erişim Tarihi: Kasım 2021.

Anonim, (2019). https://data.tuik.gov.tr/Bulten/Index?p=TurkeyHealth-Survey-2019-33661 Erişim Tarihi: Kasım 2021.

Anonim, (2021a). Çankırı Belediyesi. https://www.cankiri.bel.tr/content/45/\%C3\%87ank\%C4\%B1 r\%C4\%B1\%20Hakk\%C4\%B1nda Erişim Tarihi: Kasım 2021.

Anonim, (2021b). Kırsal Kalkınma Ajansları Genel Müdürlüğü. https://www.kalkinmakutuphanesi.gov.tr/dokuman/cankiriili-yatirim-tesvik-belgeleri-izleme-raporu-2018-2023/1555 Erişim Tarihi: Kasım 2021.

Anonim, (2021c). Çankırı Valiliği. http://www.cankiri.gov.tr/mutfak Erişim Tarihi: Kasım 2021.

Anonim, (2021d). Türk Patent ve Marka Kurumu, Coğrafi İşaretleme İstatistikleri. Erişim Tarihi: Kasım 2021. https://ci.turkpatent.gov.tr/

Anonim, (2021e). Türk Patent ve Marka Kurumu, Coğrafi İşaretleme Veri Tabanı. https://ci.turkpatent.gov.tr/veritabani Erişim Tarihi: Kasım 2021.

Anonim, (2021f). Kuzey Anadolu Kalkınma Ajansı. https://www.kuzka.gov.tr/destekler-

detay.asp?DD=302\&DesteklerDetay=cankiri-osb-haritalari Erişim Tarihi: Kasım 2021.

Artavia, G., Cortés-Herrera, C., \& Granados-Chinchilla, F.. (2021). Selected Instrumental Techniques Applied in Food and Feed: Quality, Safety and Adulteration Analysis. Foods, 10(5), 1081. https://doi.org/10.3390/foods10051081

Bech-Larsen, T., \& Scholderer, J.. (2007). Functional foods in Europe: consumer research, market experiences and regulatory aspects. Trends in Food Science \& Technology, 18(4), 231-234. https://doi.org/10.1016/j.tifs.2006.12.006

Brooks, C., Parr, L., Smith, J. M., Buchanan, D., Snioch, D., \& Hebishy, E.. (2021). A review of food fraud and food authenticity across the food supply chain, with an examination of the impact of the COVID-19 pandemic and Brexit on food industry. Food Control, 130, 108171. https://doi.org/10.1016/j.foodcont.2021.108171

Değerli, C., \& El, S. N.. (2019). Optimum beslenmede sağlıklı atıştırmalıkların yeri. Gıda / The journal of food, 988-999. https://doi.org/10.15237/gida.gd19071

Demirtepe, M., 2008. Balık yemlerinde pirina ve pirina yağ kullanımı üzerine araştırmalar (Yüksek Lisans Tezi). Ege Üniversitesi Fen Bilimleri Enstitüsü $\mathrm{Su}$ Ürünleri Yetiştiriciliği Ana Bilim Dalı, İzmir

Duru, S., \& Seçer, A.. (2019). Geleneksel Gıda Ürünlerini Satın Alma Davranışları ve Tutumları: Mersin İli Örneği. Atatürk Üniversitesi Ziraat Fakültesi Dergisi, 1-10. https://doi.org/10.17097/ataunizfd.407116

European Commission, EU Science Hub, research topic, Food Authenticity and Quality, https://ec.europa.eu/jrc/en/research-topic/food-authenticityand-quality Erişim Tarihi: Kasım 2021.
Food and Agriculture Organization of United Nations, FAO, 2021, https://www.fao.org/3/cb2863en/cb2863en.pdf Erişim Tarihi: Kasım 2021.

Güneş, EF., Aktaç, Ş., Korkmaz, İO., (2014). Tüketicilerin Gıda Etiketlerine Yönelik Tutum ve Davranışları. Akademik Gıda 12(3), 30-37 https://dergipark.org.tr/en/download/articlefile/1186469

Kalkan, i., Özarık, B., (2017). Tam Buğday Ekmeği ve Sağl1k Üzerine Etkisi. Aydın Gastronomy, 1 (1):37-46. https://dergipark.org.tr/en/download/article-file/356874

Kocatepe, D., Tırıl, A. (2014). Sağlıklı Beslenme ve Geleneksel G1dalar, Journal of Tourism and Gastronomy Studies, https://www.jotags.org/Articles/2015_vol3_issue1/2015_vol 3_issue1_article6.pdf

Molina-Alcaide, E., \& Yáñez-Ruiz, D. R.. (2008). Potential use of olive by-products in ruminant feeding: A review. Animal Feed Science and Technology, 147(1-3), 247-264. https://doi.org/10.1016/j.anifeedsci.2007.09.021

Özdemir, G. (2017). Kırsalda Kadının Geleneksel Gıda Üretimi ve Pazarlama İstekliliği. Tekirdağ Ziraat Fakültesi Dergisi, $14 \quad$ (3), 66-72. https://dergipark.org.tr/en/pub/jotaf/issue/31352/342138

Sansoucy, R. (1985). Olive by-products for animal feed. FAO Anim. Production Health, 43, FAO, Rome. http://www.fao.org/docrep/003/X6545E/X6545E00.HTM Erişim tarihi: Kasım 2021

Ulberth, F.. (2020). Tools to combat food fraud - A gap analysis. Food Chemistry, 330, 127044. https://doi.org/10.1016/j.foodchem.2020.127044

Uzun, Ö., Yağmur, C., Özer, EA. (2008). Türkiye'de üretilen bazı patates ve misırcipslerinin besin bileşimi ve enerji değerlerinin belirlenmesi, standartlara veetiket bilgilerine uygunluğunun incelenmesi, Beslenme ve Diyet Dergisi / J Nutr and Diet 35(2):53-62 https://beslenmevediyetdergisi.org/index.php/bdd/article/vie w/377/313 